\title{
Mappemonde
}

Revue trimestrielle sur l'image géographique et les formes du territoire

$126 \mid 2019$

Varia

\section{Syrian street vendors and globalisation}

Des colporteurs syriens dans la mondialisation

Los vendedores ambulantes sirios y la globalización

David Lagarde

\section{(2) OpenEdition}

Journals

Electronic version

URL: http://journals.openedition.org/mappemonde/1645

DOI: $10.4000 /$ mappemonde.1645

ISSN: $1769-7298$

\section{Publisher}

UMR ESPACE

\section{Electronic reference}

David Lagarde, «Syrian street vendors and globalisation », Mappemonde [Online], 126 | 2019, Online since 01 April 2019, connection on 11 November 2019. URL : http://journals.openedition.org/ mappemonde/1645; DOI : 10.4000/mappemonde.1645

This text was automatically generated on 11 November 2019.

\section{(c) (i) 8 (2)}

La revue Mappemonde est mise à disposition selon les termes de la Licence Creative Commons Attribution - Pas d'Utilisation Commerciale - Partage dans les Mêmes Conditions 4.0 International. 


\section{Syrian street vendors and globalisation}

Des colporteurs syriens dans la mondialisation

Los vendedores ambulantes sirios y la globalización

\section{David Lagarde}

\section{Introduction}

1 While conducting field work for my doctoral research in Amman in 2014, I met Syrian refugees from Deir Mqaren, a village in the Barada Valley, between Damascus and the Lebanese border (figure 1). Before the conflict began, most of them used to travel regularly between this region, Lebanon and Jordan, in order to sell mokasarat ${ }^{1}$, dried fruit and various kinds of sweets that they bought in Syria for subsequent sale abroad. 
Figure 1. Location of Deir Mqaren

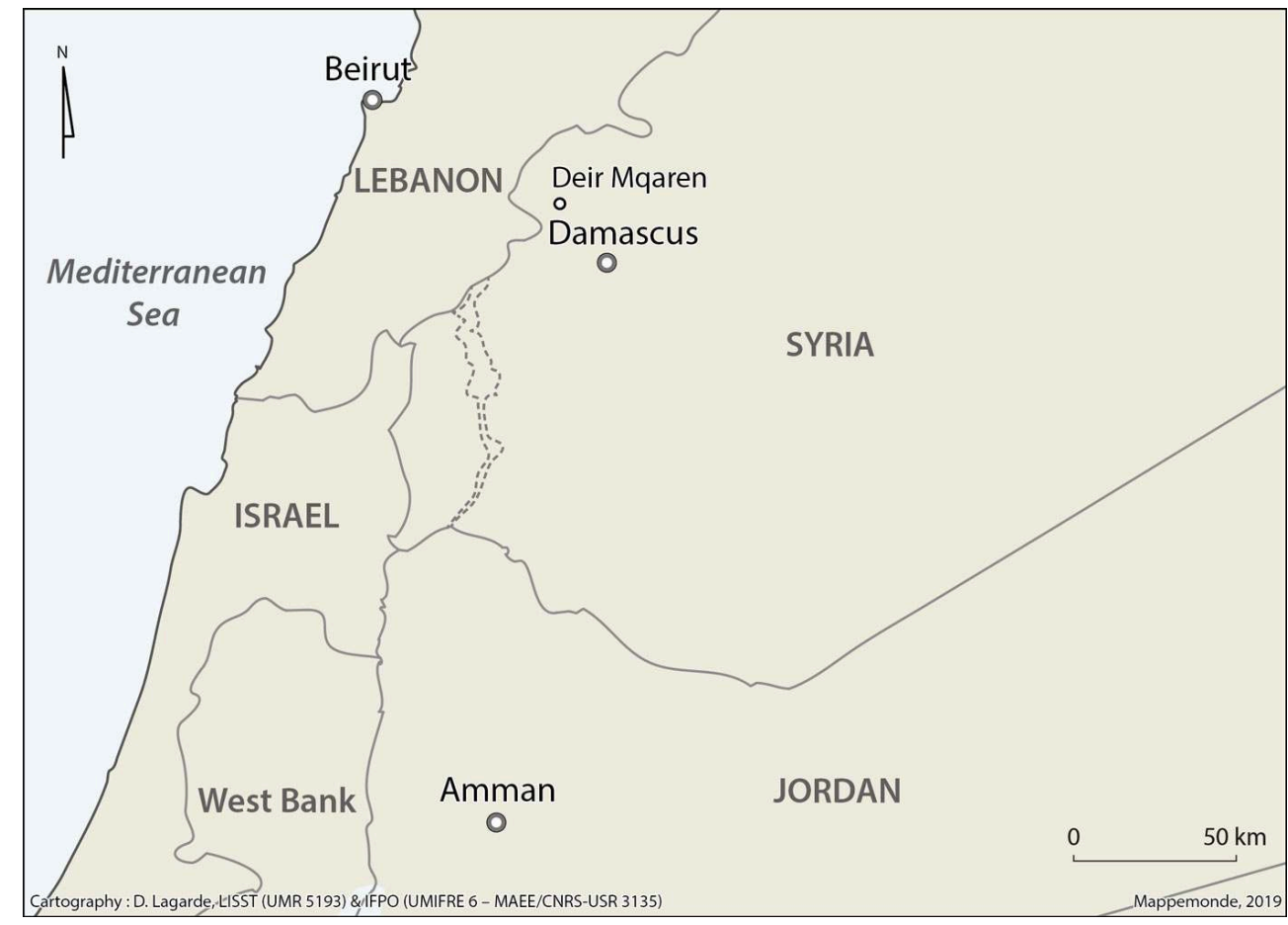

D. Lagarde

2 Inspired by the work of several contributors to this special issue [Pliez, 2007; Pliez and Belguidoum, 2012; Bouhali, 2015; Doron, 2015; Choplin and Pliez, 2018], I have endeavoured to trace the emergence of the commercial network used by itinerant traders from Deir Mqaren, its geographical distribution, and the origin of the food sold by these traders in Jordan. Although the main aim of this doctoral research was to highlight the influence of these movements on the routes currently followed by refugees from this village [Lagarde and Doraï, 2017], a longitudinal study of this commercial and migratory network also found evidence of the long-standing nature of this practice in the Middle East, while highlighting the changes in the supply chains of the itinerant traders who are the subject of my doctoral thesis [Lagarde, 2019]. This article is therefore intended to review the way in which this activity, oringinally based on exclusively local agricultural production, has gradually been grafted onto transnational networks of world trade in response to national and regional structural constraints. In doing so, it will also reveal one of the many facets that the 'discreet globalisation' [Choplin and Pliez, 2015, 2016] is likely to adopt. This facet links cities and towns in the Global South through the actions of a multiplicity of actors who are barely or not at all visibles, located away from the world's most high-profile decisionmaking and economic centres.

\section{Methodology}

When I decided to analyse the movements of the inhabitants of the village of Deir Mqaren, one of the aims was to draw up a map of international migration with a strong ethnographic flavour, the only practical way to show the 'continuum' [Richmond, 1993] between current refugee flows and pre-conflict economic mobility [Gehrig et Monsutti, 
2003]. This led me to favour the 'autonomy point of view'2' (point de vue de l'autonomie) [Ma Mung, 2009], in order to study how actors and social groups may seek to adjust the conditions of their mobility by and for themselves, whether the motivation be economic, safety-related, or both together. Favouring the point of view of autonomy ultimately means placing individual experiences at the centre of the analysis. In order to take this perspective, it seemed essential to focus attention on the life stories of Deir Mqaren's exiles. To this end, I sought to combine attentive listening with specific questions in order to reconstruct a day-to-day account of the biographical events of 24 people from this village, who have now settled in Jordan. This panel of 24 individuals consists of 7 women $^{3}$ and 17 men. All of the latter have worked as itinerant traders at least once in their lives, for periods ranging from a few months to several years. It should also be noted that of these 17 men, 4 had never done this work before their families moved to Amman following the outbreak of the conflict in Syria.

4 This profoundly qualitative approach quickly led me to question the characteristics of the 'mobility system' [Cortes, 1998] of the inhabitants of this village over the long period of Syrian migration to the Middle East. For this purpose, I have focused on collecting stories that bring together memories from multiple generations, using investigative techniques taken from oral history [Descamps, 2006]. This aspect of my research enabled me to identify the main characteristics of the daily lives of the inhabitants of Deir Mqaren since the beginning of the 20th century, in particular the way their trading routes varied with the seasons. The semi-directive interviews I conducted with the 24 respondents ${ }^{4}$ also helped me understand the specific features of the more recent movements linking Deir Mqaren to the main cities of Jordan; that is, between the mid-1980s and the end of my Jordanian survey in December 2015. These interview techniques were also combined with phases of observer-participant research, conducted in 2014 and 2015 in the homes of the exiles of Deir Mqaren in Jordan, and to a lesser extent in the places where they sold their goods, particularly in Amman. In this way, I was gradually able to identify the changes in their sources of supply of goods and to acquire a general idea of the commercial networks within which they have been trading since the beginning of the last century.

\section{Changes in the origin of the mokasarat sold around the Mediterranean}

5 Although the first references to the trade in nuts and dried fruit in the Mediterranean date back to Antiquity, it was really in medieval times that a flourishing trade in this type of product grew up, fuelling exchanges between the various trading centres in the region [Puig, 2005]. Since the Middle Ages, almonds, walnuts, pine nuts, hazelnuts, pistachios, figs and apricots have been among the main varieties produced and traded around the Mediterranean basin. Nevertheless, during the $20^{\text {th }}$ century, the growing liberalisation of global trade led to a major restructuring of supply chains, changes in consumption patterns, and also changes in consumer demand.

6 Today, these products are consumed daily in the southern and eastern Mediterranean. While the countries around the Mediterranean continue to produce large quantities of figs and dried apricots, and Turkey is still by far the world's largest producer of hazelnuts ${ }^{5}$, most mokasarat now comes from Africa, America and Asia. This trend has also led to a diversification of the nuts in these blends. Indeed, peanuts, cashews and 
macadamia nuts have now been included for several decades in these assortments, which are highly prized by the inhabitants of the Mediterranean region. The mokasarat displayed on the stalls of the souks of the Maghreb and the Near East and in Balkan bazaars now come from all over the world. In Syria, however, until the early 1980s, the inhabitants of Deir Mqaren continued to sell exclusively nuts, almonds, hazelnuts, grapes, figs or dried apricots from their own orchards, located on the banks of the Barada and the plateau facing the village.

\section{Fruit farming and trading itineraries at the beginning of the 20th century}

7 Deir Mqaren is in the Anti-Lebanon Mountains, about 20 kilometres northwest of Damascus. The Barada River flows through the village, an endorheic river that rises in the plain near Al Zabadani (figure 2). For centuries, this river was an essential resource for the people of the Barada Valley, who lived mainly from what they produced in their own orchards [Thoumin, 1936]. At the beginning of the $20^{\text {th }}$ century, the inhabitants of Deir Mqaren lived according to the agricultural calendar and the seasonal itineraries followed by farmer-traders who sold their crops in Damascus, Lebanon, Mandatory Palestine and the Left Bank of the River Jordan. Thanks to the freedom of movement enjoyed by the inhabitants of the region at the time throughout the Bilad al-Sham ${ }^{6}$, Deir Mqaren's menfolk were able to go freely to these regions to sell part of their produce, which was dried at the end of the summer and in early autumn. One of the respondents, Bashar', told me about the specific features of these seasonal journeys. 'My father ... owned several plots of agricultural land in Deir Mqaren, but this did not prevent him from working closely with the other inhabitants of the village... In the summer, they were busy harvesting fruit in the orchards, beginning in May.' In late autumn, the village men loaded their donkeys with stocks of nuts and fruit that had been dried in the sun over the previous months, and set off in groups to Lebanon to sell part of their produce. According to Bashar, their main points of sale were around the towns of Bhamdoun, Byblos and Tyre. 'They particularly favoured the villages and districts of the cities where Christians resided, who bought their dried fruit and nuts in preparation for Christmas. Then, once they had sold all they were carrying, they would go back to the village for another load, before leaving again towards the end of January for Palestine and [what is now] Jordan. This route took them to Jerusalem, where they left their donkeys in stables and loaded their kharij ${ }^{8}$ to sell their goods on foot, in the surrounding villages, as their descendants continue to do today. They then went back up to Deir Mqaren, hawking the rest of their produce in the towns and villages they passed through.' (figure 3). 
Figure 2. Zabadani plain \& Barada valley in the 1920s and 1930s

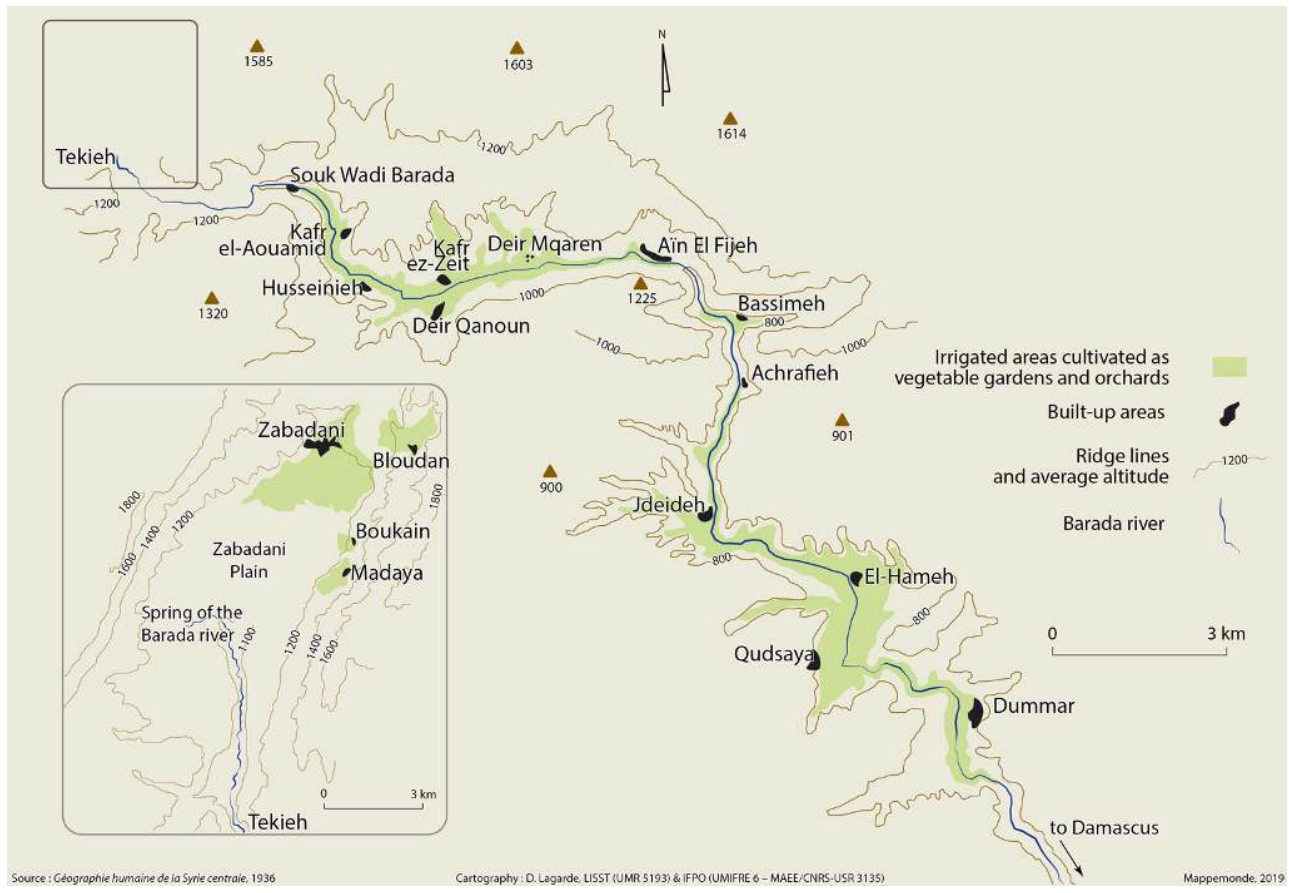

After a map by Richard Thoumin (1936)

D. Lagarde, may 2017, after Richard Thoumin, Géographie humaine de la Syrie centrale (1936) 
Figure 3. Seasonal routes of Deir Mqaren's merchants during the first half of the XXth century

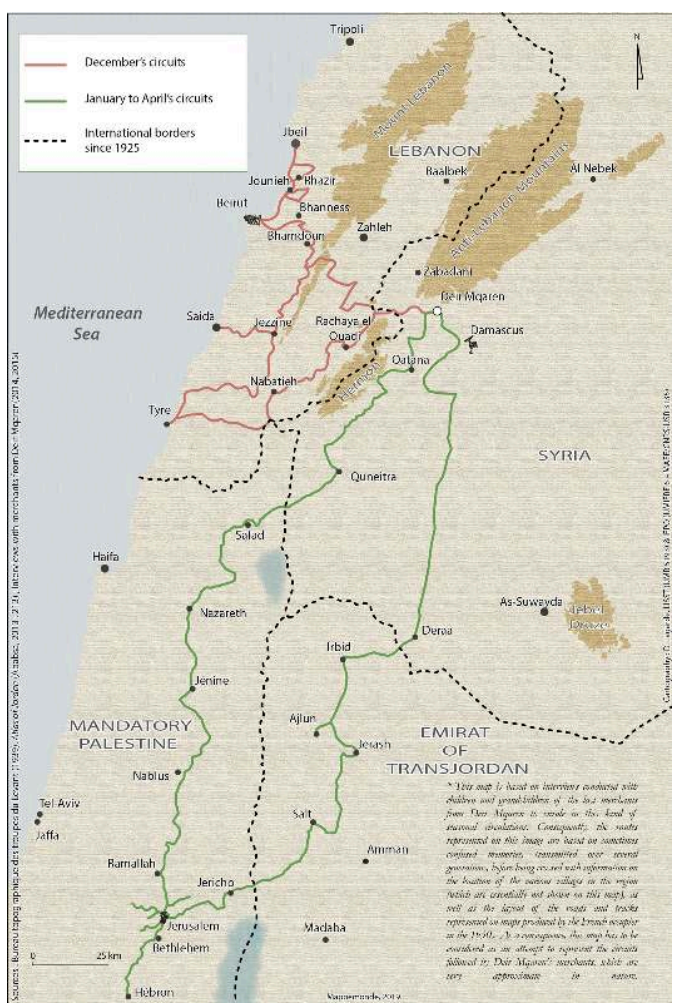

This map is based on interviews conducted with children and grandchildren of the last merchants from Deir Mqaren to enrole in this kind of seasonal circulations. Consequently, the routes represented on this image are based on sometimes confused memories, transmitted over several generations, before being crossed with information on the location of the various villages in the region (which are essentially not shown on this map), as well as the layout of the roads and tracks represented on maps produced by the French occupier in the 1930s. As a consequence, this map has to be considered as an attempt to represent the circuits followed by Deir Mqaren's merchants, which are very approximate in nature.

Sources: Bureau topographique des troupes du Levant (1939) ; Atlas of Jordan (Ababsa, 2013: 213) ; Interviews with merchants from Deir Mqaren (2014, 2015); D. Lagarde, June 2017

8 These practices and circuits, which cannot be traced back to any precise origin, seem to have laid the foundations for a market system that has been a central source of income for several generations of villagers. The earliest users of these circuits thus opened trade routes linking Deir Mqaren to other points of sale and social life elsewhere in the region. While accumulating the know-how to sell local agricultural produce, they also acquired knowledge about travelling that has been passed down over several generations [Tarrius, 1996], thereby helping 'to empower' this group [Missaoui and Tarrius, 2006] in the face of the centralizing and authoritarian regimes that have succeeded one another in Syria since the 1960s. However, their descendants still had to be very adaptable in order to maintain this market network in a political and economic context that was often unfavourable to the inhabitants of the Barada Valley. Indeed, according to the nostalgic accounts - which are undoubtedly somewhat idealised - that the population of Deir Mqaren has passed on from generation to generation, the landscape and rhythm of life of this Syrian region seem to have remained the same until the turn of the $20^{\text {th }}$ century, after which several structural constraints profoundly reshaped the characteristics of both their agricultural and commercial activities 


\section{Political events that destroyed the valley's agricultural sector.}

In 1948, the violence that followed the creation of the State of Israel provided the first act of the Arab-Israeli conflict and led the authorities of the Jewish State to apply very strict controls at border crossings [Derriennic, 1974]. For the peasant traders of Deir Mqaren, these measures significantly reduced their marketing areas, resulting in a first round of losses to their marketing network, and causing them to refocus their activities on Lebanon and the northern territory of Jordan. In 1963, the Ba'ath party seized power and imposed a series of major agrarian reforms in Syria, accompanied by rapid industrial development and constant strengthening of the power of the army, particularly once General Hafez al-Assad came to power. ${ }^{9}$ [Longuenesse, 1979; Seurat, 1979; Picard, 2013]. These major politico-military changes led to a significant centralisation, bringing about several waves of internal migration. Thus, throughout the second half of the $20^{\text {th }}$ century, the Damascus metropolitan area was under constant demographic pressure. Between the censuses of 1960 and 2004, the capital grew from about 530,000 to 3.5 million inhabitants. In terms of urban planning, this phenomenon resulted in a rapid encroachment on the Ghouta agricultural area ${ }^{10}$, as military camps, industrial areas and countless informal housing units sprang up all over [Balanche, 2009]. The ecological and health consequences of this urban and demographic explosion were disastrous [Bianquis, 1977; Balanche, 2006], far beyond the immediate surroundings of Damascus itself [Châtel, 2014]. Indeed, in the 1990s, the capital's water needs became such that 'the authorities decided to drill a series of 120 boreholes around the source of the Barada', [Châtel and Raba'a, 2014] to bring water to Damascus by pumping it across the valley. While this provided a temporary response to the risk of water shortage for the inhabitants of Damascus, it also caused the river to practically run dry during low water periods. Finally, in the name of its fight against the 'Zionist enemy' and on the strength of 'two laws passed in 1958 and 1983 allowing the government to requisition land for projects of public interest' [Châtel and Raba'a, $2014: 12]$, several hundred hectares were expropriated by the Ministry of Defence in the Barada Valley. For the farmers of Deir Mqaren, these measures resulted in the loss of their orchards located at the top of the gorges facing the village (figure 4). 


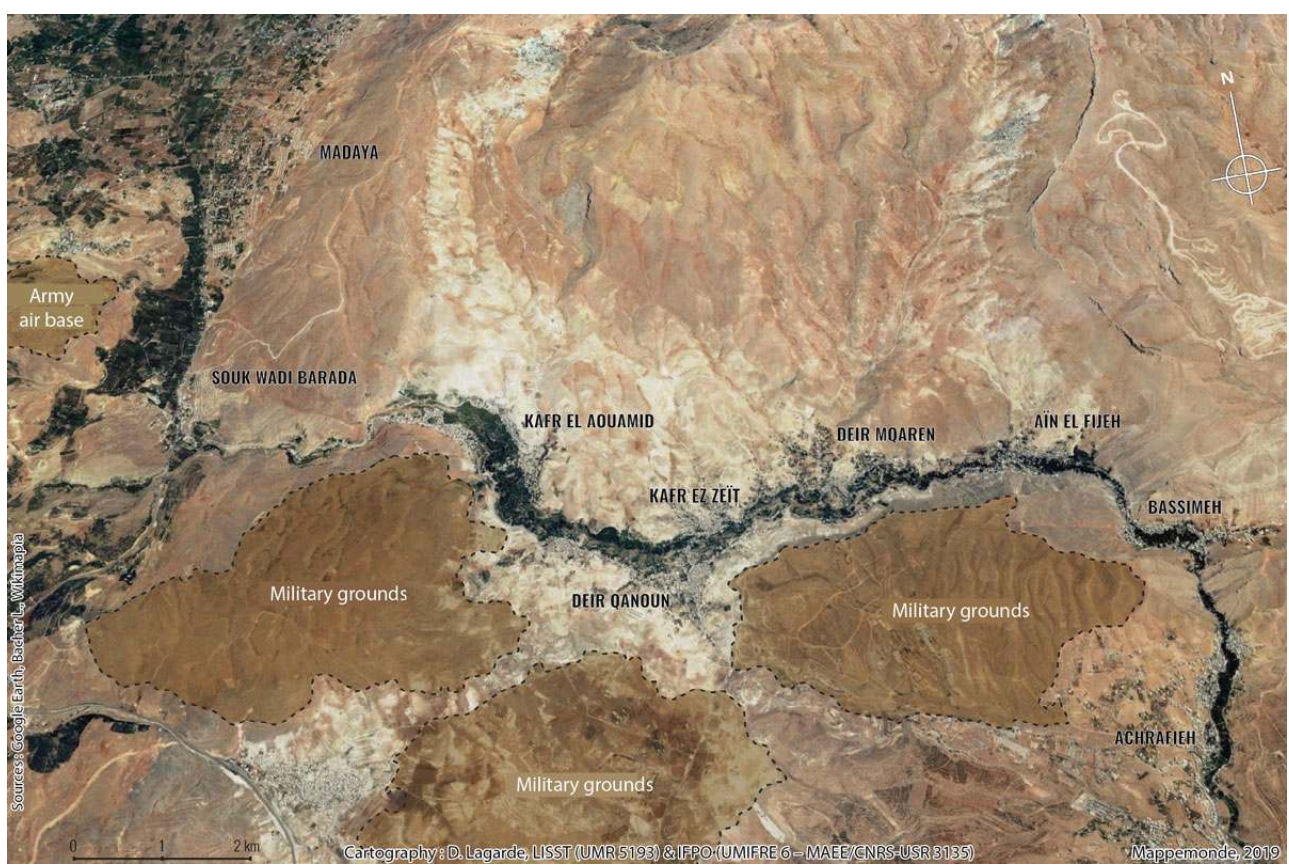

A village located in a strategic and highly militarised valley.

Sources: Satellite images: Google Earth. Location of military grounds: Wikimapia \& interview with Bachar L.; D. Lagarde

Between the early 1970 s and the late 1980s, the expropriation of agricultural land, combined with the gradual drying up of the Barada, wrought a fatal blow to the valley's agricultural sector. Yields fell so low in Deir Mqaren that the income from agriculture was no longer sufficient to support the village's population, which had been growing steadily since the beginning of the century ${ }^{11}$. Faced with this situation, villagers were forced to find alternative sources of income.

\section{Gradual connection to international supply chains}

11 In the mid-1980s, the severe lack of employment opportunities in the valley prompted several men from Deir Mqaren to approach wholesalers from Damascus who operated in the Ghouta. The idea was to obtain produce that they themselves had still been growing locally up until a few years previously, but from elsewhere. These traders therefore finally abandoned the seasonal routes used for decades by the village's producers and itinerant traders who had gone before them, in order to join a circular trading system which, until the outbreak of the Syrian conflict, led several hundred people from Deir Mqaren to travel regularly to the main cities of Lebanon and Jordan in order to find better selling prices for the nuts and sweets they had purchased at lower cost in Syria. According to Karam, a Jordanian wholesaler who has been working with the village's itinerant traders since 1992, the mokasarat and dried fruit they brought back from Syria came mainly from the Aleppo region, Turkey, and from other parts of the world ${ }^{12}$. They also purchased sweets produced in factories in Damascus, while some sellers bought them at more competitive prices directly in Jordan, through Karam himself. Finally, some merchants also acquired some of these goods in duty-free shops located at the border crossing separating Syria from Jordan. 
12 At the beginning of this cycle of circular migration, which began in the mid-1980s, those involved simply sold their goods in the city of Amman, always staying at the alHamra, a cheap hotel located in the heart of the souk in the lower part of the city (figure 5). Throughout the first half of the 1990s, following Iraq's invasion of Kuwait, the capital injected into the kingdom's economy by the 300,000 or so Jordanians returning from the Gulf stimulated the real estate sector. New neighbourhoods developed to the west of the capital, while new shopping areas sprang up in the working-class neighbourhoods of the city centre. This boosted trade for the itinerant merchants, encouraging an increasing number of inhabitants of Deir Mqaren to engage in this business, some even giving up their jobs in Syria to embark on a career as itinerant traders. The latest entrants focused on new sales sectors in the capital, as well as in the city of Irbid, which was also experiencing sustained growth at the time. These merchants started travelling to other Jordanian cities, Zarqa, Madaba, Jerash, Tafileh and Maan, while also covering each of the surrounding areas by vehicle or on foot (figure 6). For several decades, these itinerant traders supported the families who had stayed at home in the village by constant round trips between Deir Mqaren and their various sales areas in Jordan, until the Syrian conflict made it more difficult to trade across the border.

Figure 5. Amman city's central districts

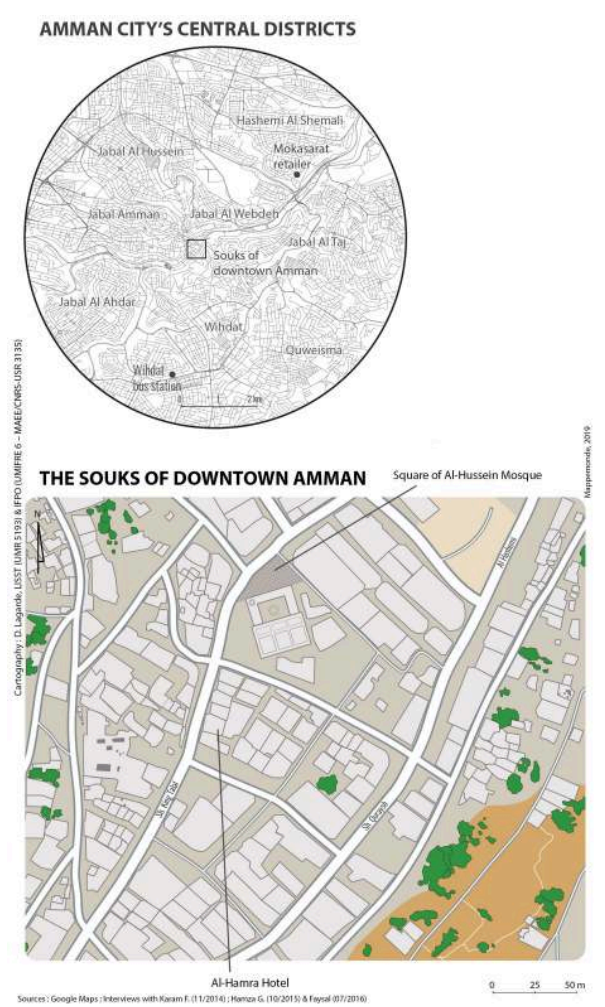

Sources: Google Maps; Interview with Karam F. on Jordanian roads (November 2014); Hamza G. in Irbid (October 2015) \& Faysal in Dortmund (July 2016); D. Lagarde, September 2017 
Figure 6. A transnational network leading to a "mobility system"

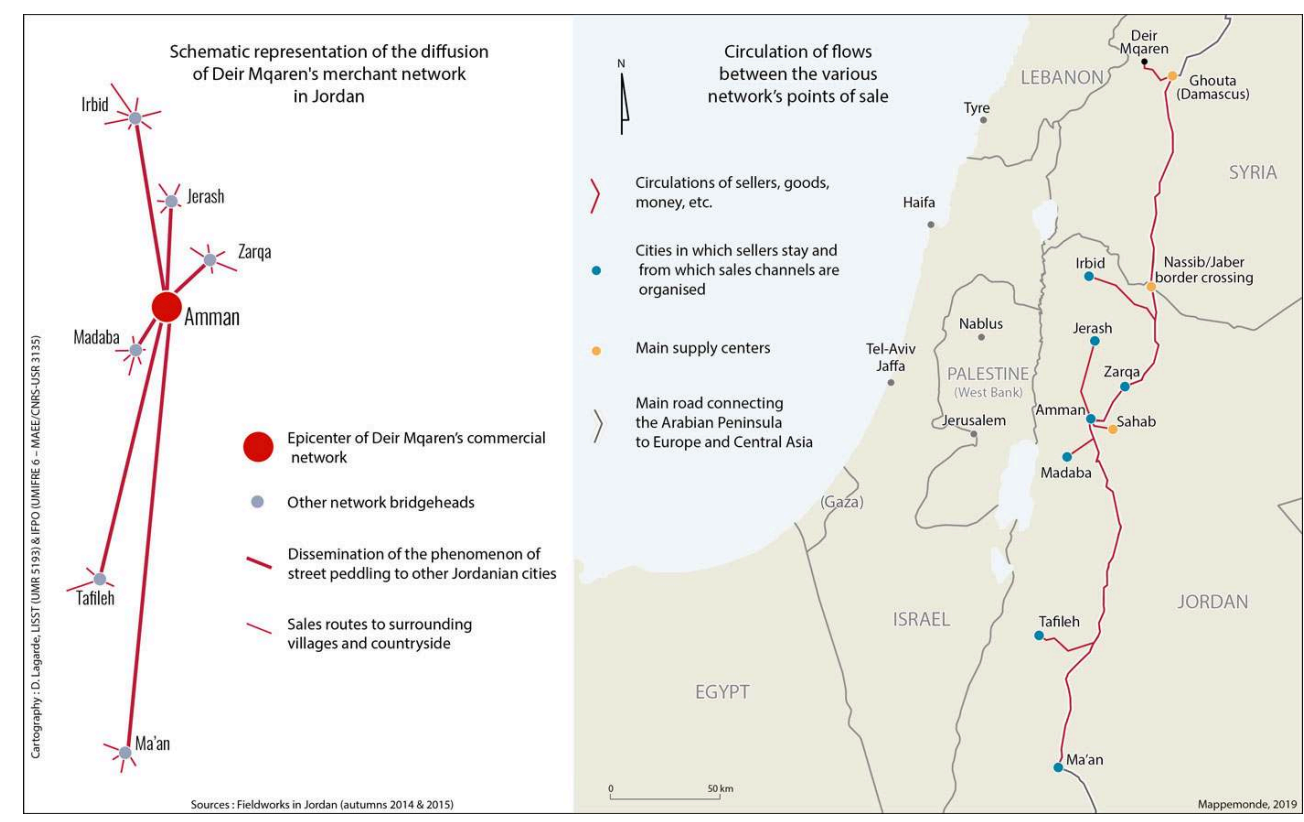

Sources: Fieldworks in Jordan (autumns 2014 \& 2015); D. Lagarde, August 2017

\section{A commercial network that provided income in times of crisis}

From March 2011, when the first demonstrations occurred in the city of Deraa, a peaceful protest movement against the Bashar al-Assad regime started to spread to other cities and towns in Syria. Despite hold-ups and searches at checkpoints on the roads in the south of the country or at the Nassib/Jaber border crossing, which could sometimes be protracted, Deir Mqaren's itinerant traders continued their round trips with Jordan as much as possible. But in February 2012, as the insurgency intensified in the Barada Valley, the regime began to make regular attacks on the village population, raining down mortar fire from military posts on the surrounding plateaux (figure 4). In this context, the traders became increasingly reluctant to leave their families and most gave up travelling abroad to work.

In July of that year there was a considerable increase in violence in the rest of the country. This was particularly the case in the city centres of Aleppo and Damascus, Syria's two political and economic powerhouses, which until then had been relatively spared from violence. While this situation brought in even more Syrians of both sexes who had already been seeking refuge in neighbouring countries for several months [Lagarde, 2019], it also dragged the country into a deep economic crisis. As Syria became bogged down in violent conflict and borders became more and more difficult to cross, itinerant trading abroad was increasingly seen as the only possible source of income for a growing proportion of the population of Deir Mqaren. Indeed, itinerant traders forced to cease their activity saw their savings shrink in only a few months. Some of them therefore decided to move to Jordan, alone or with their families. At the same time, the rapid deterioration of the Syrian economy and the resulting increase in layoffs also led villagers employed in other sectors of activity in Syria to convert to 
peddling small food items, like Mahmoud. 'Even though itinerant vending brought in quite a bit of money for some of my relatives, I always preferred to keep my job in Syria so as to continue living there permanently, because I wasn't too keen on the idea of spending whole weeks away from my family and friends. But in 2012, with the problems in the country, business started to slow, and my boss finally fired me when the fighting hit the capital. When I found myself unemployed ... street vending actually seemed the obvious solution; at least as the easiest option to find some income quickly.'

The men who moved into street vending from 2012 tended to join up with cousins, brothers and those friends in the village to whom they felt closest. By joining a collective to which they were linked by village and/or family affiliations, in groups with a strong spirit of solidarity and possessing their own resources, they were able to settle much more easily into the urban fabric of the cities where they arrived. Indeed, in addition to finding shelter with relatives who already had accommodation in Jordan, they also benefited from their advice when it came to choosing their sales areas and obtaining supplies of goods in Jordan itself.

\section{From one end to the other of a globalised supply chain: Starting in Jordan}

From my very first interviews with Deir Mqaren traders recently settled in Jordan, I tried to find out the exact origin of the produce they sold on the streets of the capital and other cities in the north of the kingdom. Except for one respondent, who told me that he continued to acquire supplies from Syria through expensive clandestine channels, they all told me that they were now only going through Karam, the Jordanian wholesaler, to obtain their goods. Specifically, the sweets came from the confectionery factory that the latter opened in 2000 in Sahab, an industrial district in southeast Amman (figure 5).

Indeed, much of this wholesaler's turnover has been coming from sales to Deir Mqaren's itinerant traders for some fifteen years. In the early 1990s, when Karam first met these village vendors, he was in his twenties and had just started trading in small food items. One day, as he came out of the downtown mosque, he noticed a stall where three men were selling dried fruit, mokasarat and malbans ${ }^{13}$. 'As I was just starting to sell similar products, I went to look more closely at what they were selling... We talked about the origin and price of their products... I offered to sell them some items at better prices than their Syrian suppliers; and that's how we started working together. I sold them sweets and in exchange they brought me back dried figs, almonds and pistachios from Aleppo... By the late 1990s, I was selling so many malbans and chata matas ${ }^{14}$ to the village traders that I decided to open my own production plant... In the 2000s, about 500 Deir Mqaren guys were selling sweets and mokasarat in Jordan and Lebanon. With the constant coming and going among the traders, there were always about a hundred people on average working in the country... Before the conflict began, the people of the village formed nearly $80 \%$ of my clientele.'

In addition to his confectionery business, Karam also supplies Deir Mqaren's traders with mokasarat. In order to find out where these nuts were produced, in November 2015 I returned to the wholesaler's in Amman where Karam gets his supplies that I had visited with him the previous year, while I was accompanying him on his rounds 
supplying some Deir Mqaren traders living near Ajlun, a town in northwest Jordan. When Karam's name was mentioned, the owner immediately agreed to show me round his 'back office', where seven employees - Syrians, Egyptians and Palestinians - were busy roasting pumpkin seeds and peanuts in a small room, where the machines produced considerable heat and deafening noise (figure 7). When I questioned the staff, I was soon able to learn the origin of this merchandise. Cashews generally come from India, peanuts from Sudan, pistachios from Iran, almonds from the United States, hazelnuts from Turkey, and pumpkin and sunflower seeds from Egypt (figure 8). This is very different from the time when Deir Mqaren's traders lived entirely on the sale of fruit grown in their own village. This itinerant sales activity is now partly integrated in a global market, in which the people I interviewed represent only the last link in a long chain of actors and places that form the backbone of one of the countless routes of the transnational trade in nuts.

Figure 7. Mokasarat workshop in Amman

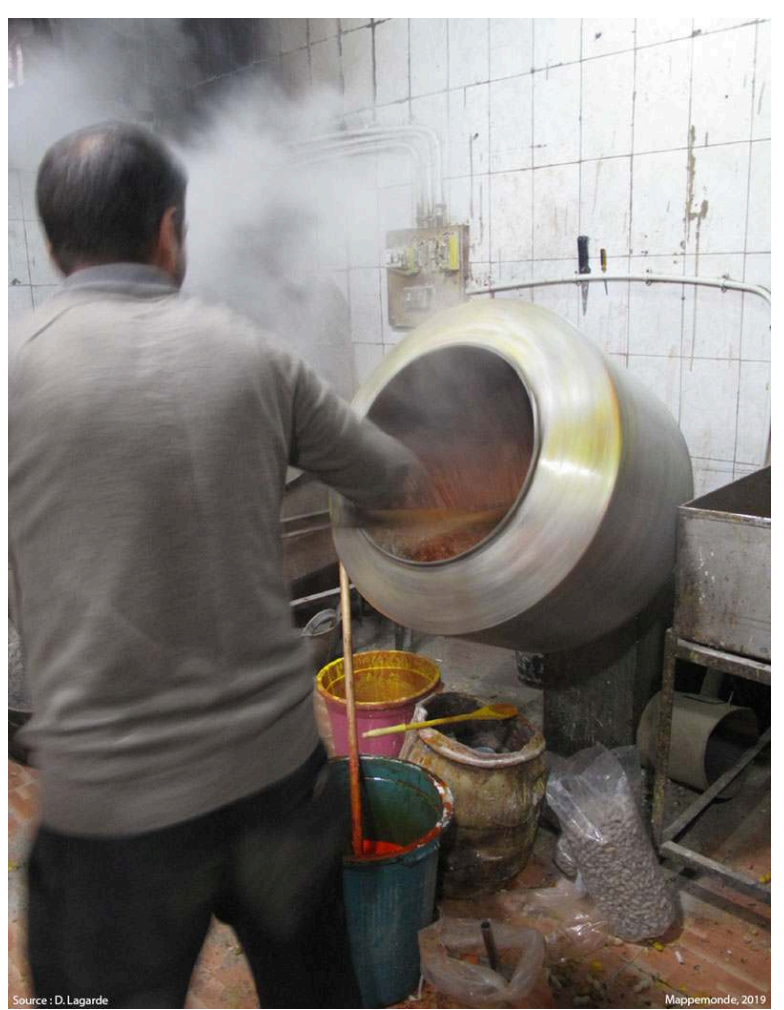

Since the beginning of the Syrian crisis, most of the goods sold by Deir Mqaren's traders in Jordan have come from here.

D. Lagarde 


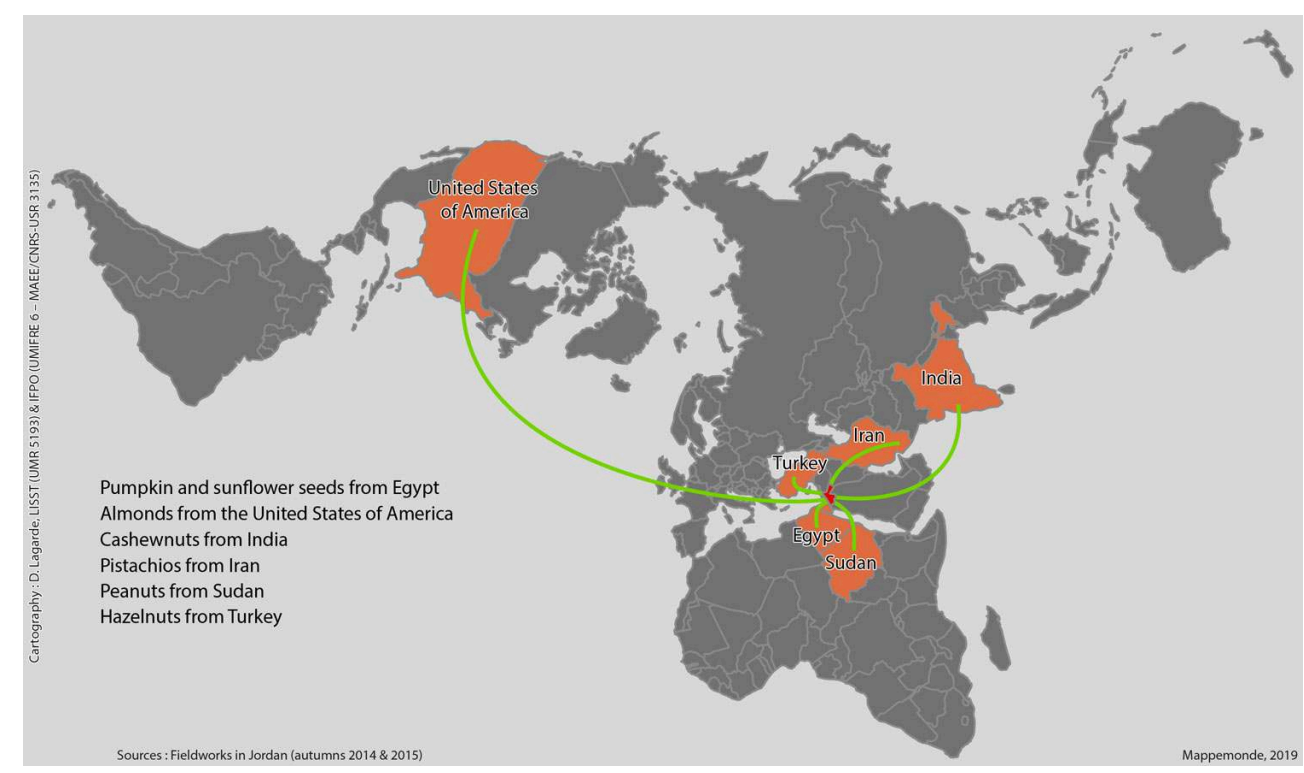

Sources: Fieldworks in Jordan; D. Lagarde, June 2017

\section{From one end to the other of a globalised supply chain: Ending in Iran}

During a visit to Iran in August 2016, I visited the city of Kerman, the capital of the province of the same name. This city, located on one of the parts of the old Silk Road in the south-east of the country, has been known since the $15^{\text {th }}$ century for its Persian carpet workshops [Necipoğlu and Leal, 2009 :336-337], and more recently as one of the main pistachio production centres on the world market (figure 9). With the gradual lifting of international sanctions against the Iranian regime, trade opportunities are increasing ${ }^{15}$ for entrepreneurs in the region, many of whom who have made fortunes exporting this particularly expensive nut. At the same time, the increasing demand for these products from China provides new opportunities in Asia, where they also invest in other activities, such as the import of manufactured goods produced in China, or high-end tourism in Iran. The opulence in which these entrepreneurs in the Iranian agri-food industry live contrasts harshly with the living conditions of the 'foot soldiers' who sell their produce in the streets of Jordan and Lebanon (figures 10 and 11). It is also ironic, and surprising, to note that this trade leads Syrian refugees, most of whom are opposed to the Bashar al-Assad regime, to buy, without even knowing it ${ }^{16}$, produce from Iran, which is one of the main economic and military backers of the current Syrian government. 
Figure 9. Pistachio packing plant in the city of Kerman (Iran)

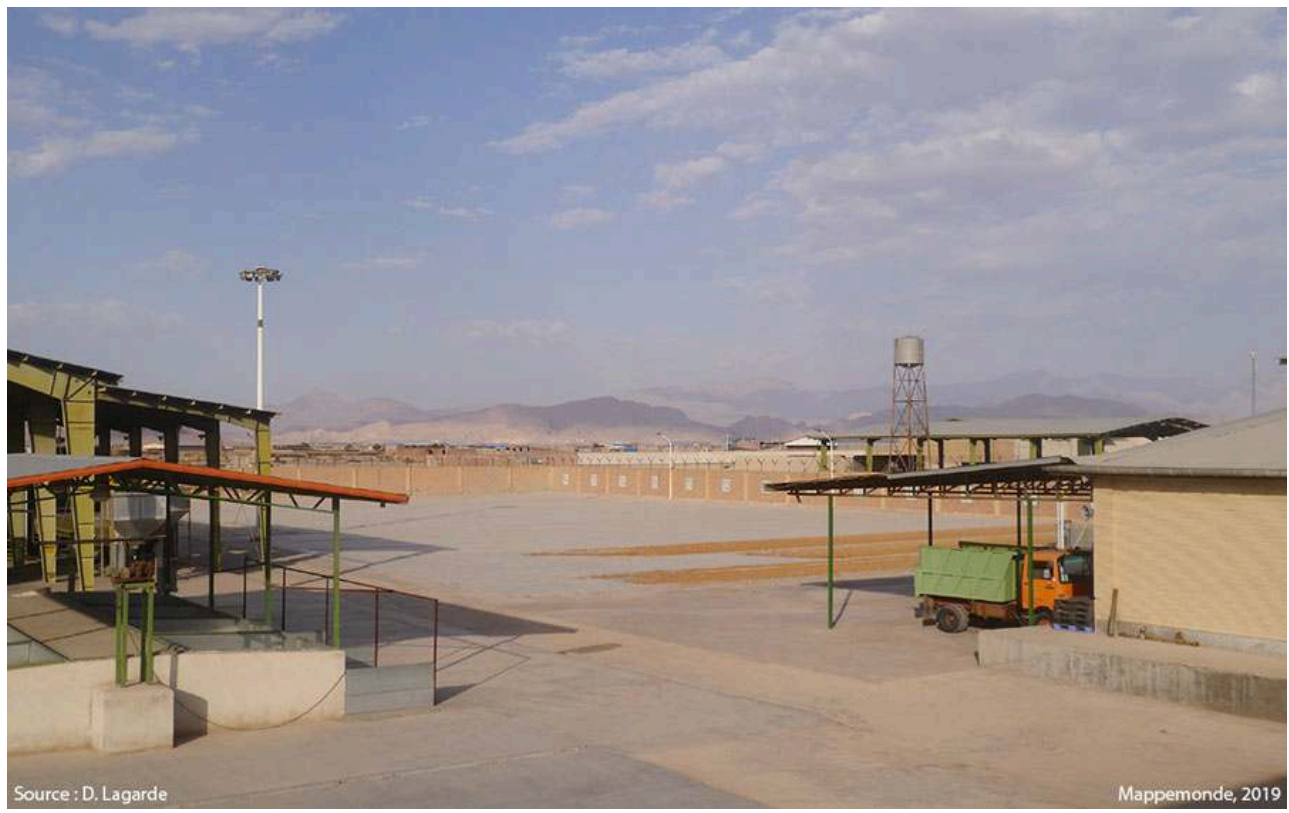

D. Lagarde

Figure 10. Street vendors selling their goods in front of the mosque in downtown Amman

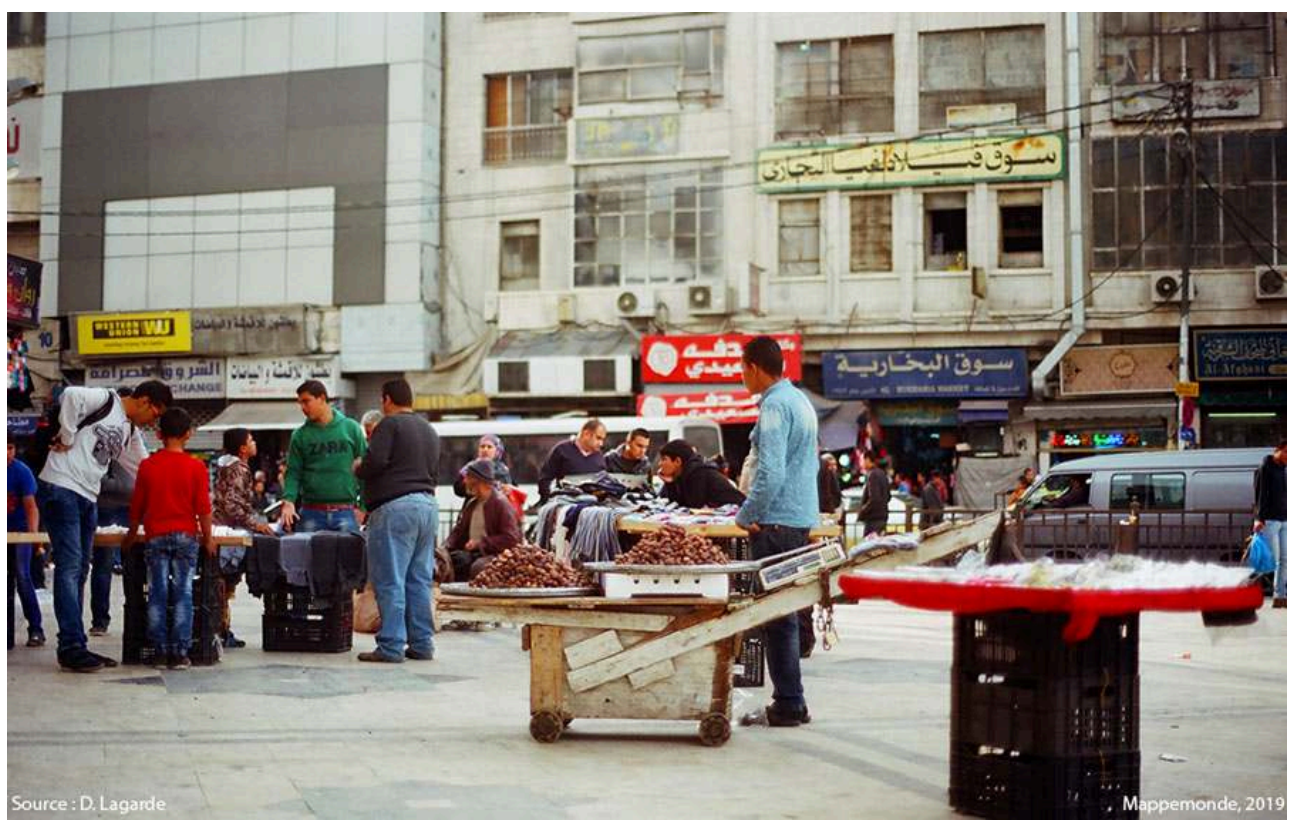

D. Lagarde 
Figure 11. The stall of a Deir Mqaren trader at the Raghdan bus station in Amman

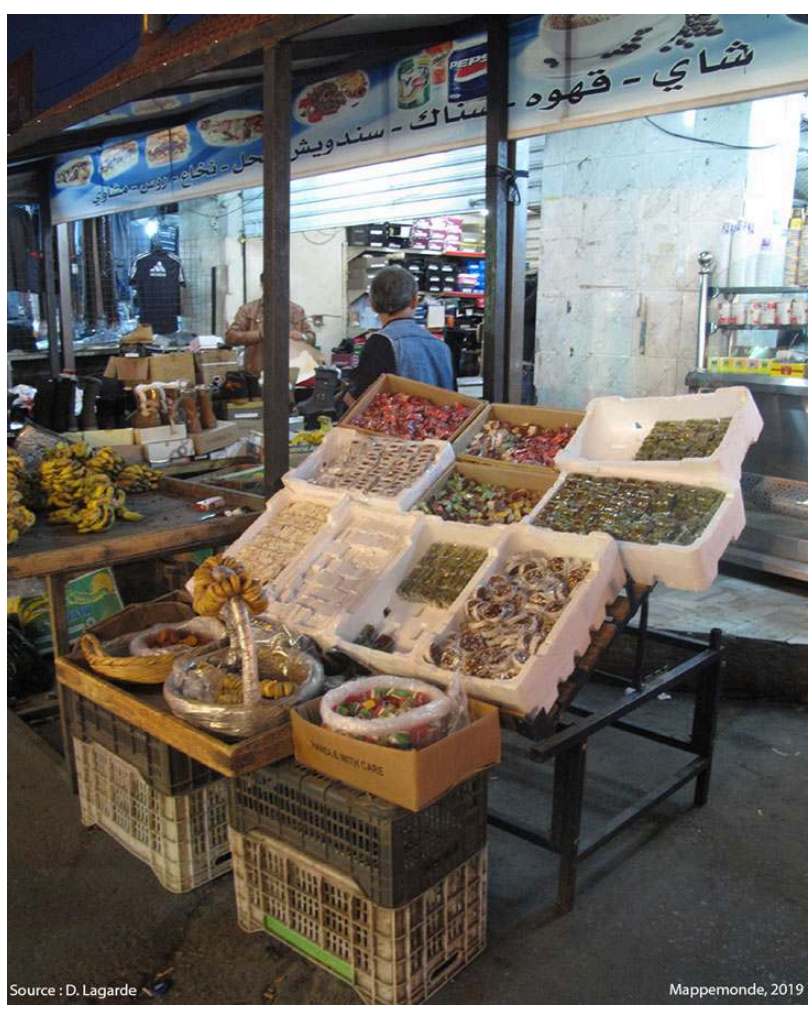

D. Lagarde

\section{Conclusion}

As this study shows, itinerant trading is an integral aspect of the collective identity of Deir Mqaren's villagers. In this respect, respondents regularly stressed the physical strength and commercial talents inherited from their ancestors who did similar work in the past, to the extent that these characteristics, in their own words, were 'part of the villagers' DNA'. Leaving aside the hypothesis of genetic evolution, there is no doubt that the transmission of a culture of mobility, acquired through the perpetuation of these trading practices since Ottoman times, has proved to be a considerable resource for several generations of Deir Mqaren residents. By changing their trading itineraries and sources of supply in order to adapt to the structural constraints they have faced several times during the $20^{\text {th }}$ century (figure 12), these peasant traders from the Barada Valley have always managed to overcome the shortage of local jobs by finding income elsewhere when it was inaccessible locally, including joining globalised supply chains, after having produced their own goods for several decades. 
Figure 12. Temporalities of the mobile sales activity in Deir Mqaren

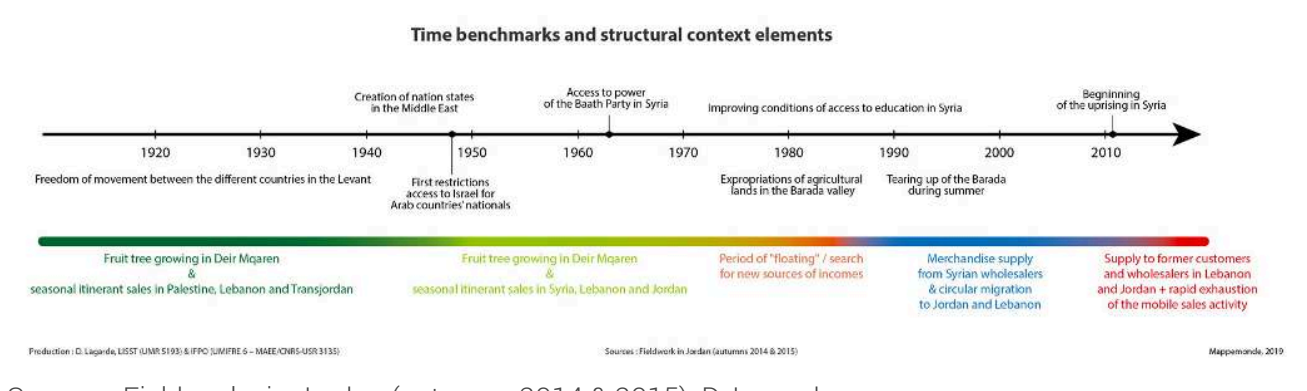

Sources: Fieldworks in Jordan (autumns 2014 \& 2015); D. Lagarde

Since 2011, the war in Syria has profoundly affected the commercial and migratory networks of these traders, as well as their working conditions [Lagarde et Doraï, 2017]. As these itinerant traders can no longer generate profits on cross-border price differences as they did before the beginning of the crisis, and are now forced to source their supplies in Jordan alone, their incomes have fallen drastically. In this context, several traders preferred to give up this business and try to rebuild their lives far from the Middle East. Although they are an extremely small minority in the total population of village exiles, most of whom are refugees in Lebanon and Jordan, some (former) itinerant traders have moved to Canada, the United States, Sweden and especially Germany. There is therefore some doubt about the future of this commercial network, and more generally about the relationship between the villagers of Deir Mqaren and the trade in small food items. Will recent geopolitical events in the Middle East result in the simple disappearance of this activity, or on the contrary, will they lead to a new reconfiguration of this system of networks? If this trade continues, what social, economic and geographical changes is it likely to undergo in the future? Will it continue to stay alive by plugging into new supply chains? Given the particularly mobile character and the great spirit of initiative that the inhabitants of this Syrian village have always shown, it would not be surprising if their spatial dispersion were to generate, in the medium term, new commercial practices between the various centres where the exiles from Deir Mqaren have settled, thus giving rise to a geographical expansion of the framework for their trade. In any case, the resilience and adaptability that Deir Mqaren's exiles continue to demonstrate in a context of crisis is well worth highlighting, if only to put into perspective the institutional and globalising visions that too often tend to portray refugees as 'passive victims of a fate over which they have no control' [Monsutti, 2004].

\section{BIBLIOGRAPHY}

BALANCHE F. (2006). « Damas : chronique d'une pénurie annoncée ». Confluences Méditerranée, vol. $58, \mathrm{n}^{\circ} 3$, p. $91-101$.

BALANCHE F. (2009). «L'habitat illégal dans l'agglomération de Damas et les carences de l'État ». Revue géographique de l'Est, vol. 49, nº 4. En ligne : https://journals.openedition.org/rge/1980 
BIANQUIS A.-M. (1977). « Le problème de l'eau à Damas et dans sa Ghouta ». Géocarrefour, vol. 52, nº 1, p. 35-53.

BouHALi A. (2015). « Médina J'dida (Oran), un quartier-marché sur les routes algériennes du commerce transnational ». Les Cahiers d'EMAM. Études sur le Monde arabe et la Méditerranée, $\mathrm{n}^{\circ} 26$. En ligne : https://journals.openedition.org/emam/889

CHATEL F. DE (2014). “The Death of the Garden of Eden”. In TVEDT T. et OESTIGAARD T.(dir.), History of Water, Londres : I. B. Tauris.

CHÂTEL F., RABA'A M. (2014). “Waterless Wadi Barada: Manufacturing scarcity in a Syrian River Valley”. Middle East Report, vol. 44, p. 10-17.

CHOPLIN A., PLIEZ O. (2015). “The Inconspicuous Spaces of Globalization”. Articulo. Journal of Urban Research, $\mathrm{n}^{\circ} 12$. En ligne : https://journals.openedition.org/articulo/2905

CHOPLIN A., PLIEZ O. (2016). « Des mondialisations plus discrètes ». La Vie des idées. En ligne : https:// laviedesidees.fr/Des-mondialisations-plus-discretes.html

CHOPLIN A., PLIEZ O. (2018). La mondialisation des pauvres. Loin de Wall St. et de Davos. Paris : Seuil.

CORTES G. (1998). « Migrations, systèmes de mobilité, espaces de vie : à la recherche de modèles ». L'Espace géographique, vol. 27, $\mathrm{n}^{\circ}$ 3, p. 265-275.

DERRIENNIC J.-P. (1974). Israël en guerre. Paris : Presses de Sciences Po.

DESCAMPS F. (2006). Les sources orales et l'histoire : récits de vie, entretiens, témoignages oraux. Paris : Éditions Bréal.

DORON A. (2015). « De la marge au monde : la structuration mouvementée d'une place marchande transnationale à Ben Gardane (Tunisie) ». Les Cahiers d'EMAM. Études sur le Monde arabe et la Méditerranée, $\mathrm{n}^{\circ}$ 26. En ligne : https://journals.openedition.org/emam/1065

GEHRIG T., MONSUTTI A. (2003). « Territoires, flux et représentations de l'exil afghan : le cas des Hazaras et des Kaboulis ». A contrario, vol. 1, n 1, p. 61-78.

LAGARDE D. (2019, forthcoming). « Du refuge moyen-oriental à la dispersion mondiale. Structuration de l'exode syrien entre 2011 et $2016 »$. Revue européenne des migrations internationales, vol. $35, \mathrm{n}^{\circ} 3 \& 4$.

LAGARDE D. (2018). Sur les routes de l'exil syrien. Récits de vie et parcours migratoires des réfugiés de Deir Mqaren. Thèse de doctorat en Géographie. Université de Toulouse Jean Jaurès.

LAGARDE D. (2019, forthcoming). « Du refuge moyen-oriental à la dispersion mondiale. Structuration de l'exode syrien entre 2011 et $2016 »$. Revue européenne des migrations internationales, vol. $35, \mathrm{n}^{\circ} 3 \& 4$.

LAGARDE D., DORAÏ K. (2017). « De la campagne syrienne aux villes jordaniennes. Un réseau marchand transfrontalier à l'épreuve du conflit syrien ». Espace, Populations, Sociétés, $\mathrm{n}^{\circ} 2$. En ligne : https://journals.openedition.org/eps/7212

LONGUENESSE É. (1979). « Monde paysan et industrialisation en Syrie ». Géocarrefour, vol. 54, nº 3, p. 249-255.

MA MUNG E. (2009). « Le point de vue de l'autonomie dans l'étude des migrations internationales : "penser de l'intérieur" les phénomènes de mobilité ». In DUREAU F. et HILY M.-A. (dir.), Les mondes de la mobilité, Presses de l'Université de Rennes, p. 25-38. 
MISSAOUI L., TARRIUS A. (2006) «Villes et migrants, du lieu-monde au lieu-passage ». Revue européenne des migrations internationales, vol. 22, $\mathrm{n}^{\circ} 2$, p. 43-65. En ligne : https:// journals.openedition.org/remi/2818

MONSUTTI A. (2004). Guerres et migrations : réseaux sociaux et stratégies économiques des Hazaras d'Afghanistan. Neuchâtel/Paris : Institut d'ethnologie/Maison des sciences de l'Homme.

NECIPOĞLU G., LEAL K. A. (2009). Muqarnas. BRILL.

PICARD É. (2013). « La Syrie de 1946 à 1979 ». In RAYMOND A. (dir.), La Syrie d'aujourd'hui, Aix-enProvence : Institut de recherches et d'études sur les mondes arabes et musulmans, p. 143-184.

PLIEZ O. (2007). « Des jeans chinois dans les rues du Caire, ou les espaces discrets de la mondialisation ». M@ppemonde, n 88-4. En ligne : https://mappemonde-archive.mgm.fr/num16/ articles/art07404.html

PLIEZ O. BELGUidoum S. (2012). « Construire une route de la soie entre l'Algérie et la Chine ». Diaspora. Histoire et sociétés, $\mathrm{n}^{\circ} 20$, p. 115-130.

PUIG C. (2005). « La place des fruits en Méditerranée nord occidental à partir des actes de la pratique et des tarifs marchands (XII ${ }^{e}-$ Première moitié XIV ${ }^{\mathrm{e}}$ siècles) ». Archéologie du Midi médiéval, t. 23-24, p. 119-128.

REIFFERS J.-L., éd. (1997). La Méditerranée aux portes de l'an 2000. Paris : Economica.

RICHMOND A. H. (1993). “Reactive Migration: Sociological Perspectives On Refugee Movements”. Journal of Refugee Studies, vol. 6, nº 1, p. 7-24.

SEURAT M. (1979). « État et paysans en Syrie ». Géocarrefour, vol. 54, n 3, p. 257-270.

TARRIUS A. (1996). « Territoires circulatoires des migrants et espaces européens ». In HIRSCHORN M. et BERTHELOT J.-M. (dir.), Mobilités et ancrages. Vers un nouveau mode de spatialisation? Paris :

L'Harmattan, p. 93-100.

THOUMIN R. (1936). Géographie humaine de la Syrie centrale. Librairie Ernest Leroux.

\section{NOTES}

1. Mokasarat is a mixture of nuts and roasted and salted seeds.

2. Emmanuel Ma-Mung defines autonomy as follows: “... 'Autonomy as know-how' could therefore be defined as the ability of a subject, whether individual or collective, to constitute and maintain a way of life, and 'autonomy as power' as the ability of the same subject to act on and transform this way of life" (Ma-Mung, 2009: 29).

3. It should be noted here that itinerant trading in Jordan, Lebanon and Syria is an exclusively male activity. None of Deir Mqaren's women ever worked as traders.

4. Of the 24 respondents, 8 were interviewed at least twice in Jordan (and 3 of them also in Germany) between October 2014 and June 2016.

5. According to the Food and Agriculture Organization of the United Nations (FAO), Turkey produced 675,000 tonnes of hazelnuts in 2017, compared to 131,281 tonnes for Italy, the world's second largest producer.

6. Bilad al-Sham is the name of the region containing the current states of Syria, Jordan, Israel, Palestine and Lebanon, formerly an economically and culturally homogeneous entity dominated by the city of Damascus.

7. The names of all respondents quoted in this article have been changed. 
8. A kind of large holder, consisting of two deep bags, worn on a strap across the shoulders.

9. Hafez al-Assad took power in Syria in November 1970 following a coup d'état and remained in power until his death in June 2000. Since then, his son Bashar has been the strong man in this country.

10. In the case of Damascus, the term Ghouta refers to the zone east of the capital that had been agricultural and which, for centuries, had been a lush oasis in the middle of the desert.

11. Since the end of the Mandate period, when Deir Mqaren had a population of 599 according to a count carried out by the Service Géographique des Forces Françaises du Levant, the village's population has grown significantly because, according to the respondents, about 5,000 people were living there in 2011. This increase is mainly due to a sharp drop in the mortality rate in Syria as a whole since the turn of the $20^{\text {th }}$ century [Reiffers, 1997]. Indeed, although some families from outside the village settled in Deir Mqaren during this period, this inflow remained marginal and cannot by itself explain such a population increase.

12. During our interview, Karam was unable to specify the other countries from which these goods were obtained.

13. Malbans are a type of confectionery that resembles a kind of soft nougat and fruit paste, made from grape juice and generally filled with nuts, usually walnuts or pistachios. In order to offer a cheaper product to the poorest consumers, peanuts are increasingly being used as substitutes. This is particularly the case for the malbans produced in Karam's factory.

14. Chata matas are large, sharp-tasting sweetmeats (containing a high proportion of colouring agents) produced in large slabs that are then cut into cubes about two centimetres thick.

15. The trading outlets of these Iranian exporters, and thus the relative economic dynamism of their companies in recent years, may have been significantly affected by the reinstatement of US sanctions against Iran in 2018.

16. It should be noted that when I tried to ask Deir Mqaren's traders about the origin of the mokasarat they sell in Jordan, none of them were able to answer my questions. They all referred me back to Karam, saying that he would be in a better position to enlighten me on the subject.

\section{ABSTRACTS}

By studying the mobility of Syrian peddlers, this article aims to highlight the adaptability of a rural community subject to the vicissitudes of geopolitical crises in the Middle East. Their history, the regular reconfigurations of their trade network, as well as the origin of the food products they sell in the streets of Jordan, reveal a hidden facet of globalization. This aspect helps connect the cities and towns of the Global South that are far removed from the most publicised political and financial centers in the world.

En étudiant les mobilités de colporteurs syriens, cet article entend souligner la capacité d'adaptation d'une communauté rurale soumise aux vicissitudes des crises géopolitiques procheorientales. Leur histoire, les reconfigurations régulières de leur réseau marchand, ainsi que l'origine des produits alimentaires qu'ils vendent dans les rues de Jordanie, révèlent en filigrane une facette peu visible de la mondialisation, qui contribue à relier entre elles des villes et des bourgades des Suds, situées à l'écart des grands centres décisionnels et économiques les plus médiatisés de la planète. 
Estudiando la movilidad de los vendedores ambulantes sirios se comprende la adaptación de las comunidades rurales ante las vicisitudes derivadas de las crisis geopolíticas en Oriente Medio. La cara oculta de la globalización se visibiliza a través de sus historias, de las reconfiguraciones periódicas de sus redes comerciales, o del origen de los alimentos que venden en las calles de Jordania. Al mismo tiempo conectan las ciudades con los núcleos rurales y diseminados del Sur que se encuentran alejado de los grandes centros económicos y decisorios del planeta.

\section{INDEX}

Subjects: Les routes de la soie existent déjà. Routes transnationales et places marchandes du made in China entre Asie Afrique et Europe

Mots-clés: colportage, commerce transfrontalier, migrations, mondialisation

Palabras claves: venta ambulante, comercio transfronterizo, migraciones, globalización

Keywords: cross-border trade, globalization, migration, street-peddling

\section{AUTHOR}

\section{DAVID LAGARDE}

CNRS postdoctoral researcher, LISST team (UMR 5193) Associate member of the Institut français du Proche-Orient (UMIFRE 6 - MAEE/CNRS-USR 3135) 